\title{
Multiple Intelligences in Learning Musical Dramas for Prospective Primary School Teachers
}

\author{
Okto Wijayanti ${ }^{1 *}$, Rukiyati ${ }^{1}$ \\ Faculty of Teacher Training and Education, Muhammadiyah University of Purwokerto, Purwokerto, \\ Indonesia \\ *wijayantiokto@gmail.com
}

Received: Januari $29^{\text {th }}, 2021$

Revised: Februari $7^{\text {th }}, 2021$

Accepted: February $09^{\text {th }}, 2021$

\begin{abstract}
Prospective teachers who get the 7th semester of Drama and Dance Education courses must have competence, one of which is that the teacher can present interesting learning for children with a drama approach, as a multidisciplinary knowledge that can be taught using role playing methods that are taught more interesting, fun, meaningful, interactive and rich experience. As a student, you can develop multiple intelligence in this subject. Programmed and scheduled musical drama training systems are indeed interesting, because each student is given the freedom to give assessments, provide reinforcement, support, correct weaknesses, mistakes and even object to the work of other groups with the strengths and points of view of the subjectivity expressed by each. students. As a result, sportsmanship is needed in this regard. Through an empirical qualitative approach, with lesson study-based inductive thinking logic. This study aims to describe the various intelligences that appear in learning dance drama, especially the work practice of dance drama projects (musical dramas), both individually and in groups obtained from the performance appraisal contained in the instrument. Important notes in the discussion found several findings about the application of Multiple Intelligences in learning dance and drama, namely: 1) Tools to achieve success that are more concerned with the process of achieving results, 2) Integrative Learning dance drama combines various intelligences, 3) Learning dance and dance drama becomes full of challenges, and more fun, 4) Care for the individual differences of students so that emotional management is needed, 5) Instructional based learning is firm and clearly measurable, 6) The importance of reflection for further improvement, 7) Clarity of goals, achievement of competence and each student's feedback needs to be done.
\end{abstract}

Keywords: dance and drama; multiple intelligences; prospective teacher.

\section{INTRODUCTION}

An elementary school teacher is known as a second parent for students. At the primary education level, the teacher becomes an idol or artist in class learning. An Primary school teacher with a teacher will be a concern for students. They can observe something trivial, so sometimes they are very critical in giving comments or responses to things that 
are inherent in the appearance of an elementary school teacher. Students will observe and give an impression of assessment related to gait, speaking style, teaching procedures or styles, how to dress, how to wear the hijab, and follow teacher updates on social media so on. This is reinforced by the statement by Zakiah Daradjat, et al., (1996) which states that a teacher must have a personality main, because the teacher is someone who should be loved, respected, and imitated by his students or students.

Seeing the situation, the attention condition must be addressed by the teacher wisely. Moreover, prospective elementary school teachers. Various responses is acquired prospective elementary school teachers when they are conducting an internship program in elementary school. Various feedback, praise, good suggestions that are critical are expressed by various characters of students with various potentials and their respective intelligences.

Intelligence, according to the paradigm of multiple intelligences (Gardner, 1993), can be defined as an ability that has three main components, namely: 1 ) the ability to solve problems that occur in everyday life - the day; 2) the ability to find new problems faced to be resolved; 3) the ability to create something or offer a service that will give rise to rewards. Each multiple intelligence occupies a different area of the brain.

The nine intelligences can be related, related or independent from one another. These nine intelligences can define the human species. In order to implement the developing teaching experience professional, prospective teacher can develop their potential through the observation through gestures and actions to see stale-aspect of multiple intelligences has, for example by doing activities that are identified characterize various types of intelligence one of them through practice the musical drama in groups of learners a $\mathrm{n}$ dance and drama. Activities in the art of dance drama learning activities that provide opportunities development facility every intelligence possessed by prospective teachers (students PGSD). Prospective teachers to get the course Education dance and drama at the 7th semester so that competence is expected that one of them is a teacher could present an interesting learning and powerful pull for children with track approach to art, drama that includes applying a multidisciplinary science can be taught using methods role playing. The method of role playing in drama can be taught in a more interesting, fun, meaningful, interactive and experience-rich way.

Dearden, R.F., Hirst P.H and Peters R.S (1975) stated the criteria for basic education teachers who are said to be of quality (professional) are those who: are able to master elementary education material; and able to understand the uniqueness and cultivate develop Multiple Intelligences children elementary age; and then, may conclude one task of a teacher who daily classroom learning with students in the classroom requires a special attention. 
The task that requires special attention by the teacher in the classroom is to be able to understand the characteristics of students with all their differences. Based on the differences in the characteristics of these students, it provides opportunities and opportunities for prospective teachers to provide learning that can facilitate various forms of characteristics, styles and uniqueness of their students with various concepts of intelligence levels. Then the intel intelligence or Multiple Intelligences one of which can be developed through learning the art of dance and drama (Siswantari \& Maretha, 2020).

Suwardi (2014) conveyed his understanding of drama is known as a collaborative art that combines physical, verbal, visual and aural dimensions. In demonstrating drama, prospective teachers will experience a development in understanding about player relationships, team play, respect, respect, cooperation, discipline and responsibility. Without these attitudes and characters, it is impossible for group drama works to be performed well. Learning in drama provides an understanding of how important an experience, process, team or group collaboration and performance means.

Students will join elements of drama to create, present and respond to representations of human situations, characters, behaviors and relationships in space and time. Prospective teachers learn to make drama through drama plays, role plays and improvisation, arrange elements to build storylines, motion, visuals, dance music, games, directing and script writing. During one semester, learning can be said to be challenging, because students (prospective teachers) are asked to have confidence in themselves in achieving learning goals (self efficacy).

In presenting drama and dance, student teacher candidates will learn, as actors, to use body and gestures, voice and language, through a process of interpretation and rehearsals. and production and performance. In response to the drama learning process, students will learn about how drama contributes to personal, social and cultural identities. They will study the diversity of purposes, forms and styles in drama and theater both contemporary and from time, place and other in cultural contexts. At the end of the seventh semester, they will present their performance with a practice schedule guided by the drama script. Observations about multiple intelligences through lesson study will be reviewed by researchers.

The emergence of various forms of intelligence possessed by prospective teachers through performances that come from experiences in arranging drama, language, dance, motion, decoration, make-up, blocking, and characterization contained in Linguistic Verbal Intelligence, Mathematical Logic Intelligence, Visual Spatial Intelligence, Musical Intelligence, Kinesthetic Intelligence, Interpersonal Intelligence, Intrapersonal Intelligence, Naturalist Intelligence, Existential Intelligence, are assumed to be provisions and assets 
after the teacher plunges into the world of teaching facing various student characteristics.

\section{THEORITICAL STUDY}

1. Conceptual Basis for the Field of Arts Education

The 2006 PGSD curriculum explains that art education is education for creative expression that can develop talents and form vocational skills. Thus, art education is a creative expression education that can develop aesthetic appreciation sensitivity, and form a whole human personality, balance both physically and mentally, with noble character in accordance with the environment and cultural context of Indonesia. So education through art is a concept that is suitable for learning in elementary schools. The implementation of art education is then presented in an integrated manner with inter fields of study and between fields of study with multidisciplinary learning.

2. The Function of Dance and Drama in Elementary Schools

Dance and drama taught in elementary schools do not merely shape students into dancers and artists, but there are several important things or functions. St. Y Slamet (2016) conveyed the following functions of dance and drama, namely:

1.The function of dance to help children's growth and development includes: a. Dance and drama education can improve physical, mental and aesthetic growth.

b. Dance and drama education contribute to self-awareness.

c. Dance and drama education fosters creative imagination.

d. Drama dance education contributes to problem solving.

e. Dance and drama refine ways of thinking, acting and judging.

f. Dance and drama education contributes to personality development.

g. Dance and drama education fosters physical development.

h. Dance and drama help improve life.

3. Teacher Profiles Needed to Guide Dance and Drama Experiences

Purwatiningsih (2002) describes the teacher profile needed to guide dance and drama is the ideal attitude and appearance. In understanding the experience of children's dance-drama, it generally depends on the age and interest of each child in different art experiences. Experiences of child drama dance that give rise to uniqueness include exploring attitudes in children, childhood is a period of fantasy, the process of finding facts, and learning through expression activities in art. The teacher profiles needed to guide dancedrama in elementary schools are teachers who act as friends, teachers who are creative and sensitive (sensitive), as well as teachers who are emotionally and intellectually mature. Teachers must be able to understand 
themselves (teacher profiles) which can guide learning dance and drama through various experiences of drama dance for each individual, understanding the talents and needs of students at the elementary school level.

4. Howard Garner (1983) said that basically humans have various forms of intelligence:

1) Linguistic Verbal Intelligence

Definition of Verbal on linguistic ability is capacity of using words effectively, both orally and in writing that can be developed with writing essays, experiences, writing daily journals and the like. Linguistic intelligence is also called verbal intelligence relating to upon ability to express themselves verbally and te $r$ stationery, as well as mastery language. Linguistic verbal intelligence is usually owned by artists, presenters, soap operas, television broadcasters, orators, spokesmen, campaigners and others. Observing student learning in the Dance and Drama Education course, the competence in this case is more on the ability to compose words, sound sensitivity. As in practice play musical in groups, students' ability to argue, discuss and debate, and to convey the idea of ideas is emphasized so that raises the critical analysis student in deciding on a topic, plot or storyline, drafted the manuscript came to demonstrate what the exam end of semester practice. Implementation of learning the art of dance and drama in the work of this group, for example musical drama takes the theme of the story of animals or fabel. Some of the steps to develop linguistic intelligence in students are almost the same (adopting children's learning) with PAUD children's learning, although eventually they are applied to learning in elementary schools. Only in practice can it be more complex because it is already positioned by higher education students.

2). Intelligence logic of mathematics

Lwin (2003) explains that logicalmathematical intelligence relates to the ability to resolve the problems related to counting early counting. This ability is broadly owned by scientists, scientists, mathematicians, physicists, philosophers. This intelligence has two intelligence elements intelligence mathematics and logic. The characteristics of children ages 1 to 6 years who have intelligence mathematical logic that is well able to recognize objects, colors, shapes, flavors, numbers, classifying objects, differentiating shape wake space, flat wake of discerning taste and color, distinguishing shapes and sizes, sequence numbers, distinguishing colors, show curiosity about how things work, like unpacking toys and reassembling, sort something in the order of large and small, were able to sort the numbers until five thirty, playful computer, and can classify objects correctly.

3) Visual spatial intelligence

This intelligence in the form of the ability to perceive the visual world is accurate, forming the ability to use their senses of sight and the ability for me $n$ visualize objects, including the ability to be creative image-mentally me painting. 
Children ages 1 to 6 years old who have a visual intelligence high spatial according Suyadi (2010: 161) is pleased to see pictures of colorful, enjoy goods ma in his own, pay attention to the object attentively, able to draw, able to make playthings with various tools, able to understand the game of puzzles, able to make the composition of the colour of the painting itself and see it with the sharpness particular, able to imagine or describe objects ever seen with creative, able to calculate how fast, and capable of making anything like that pictured in his imagination.

4) Musical intelligence

Rhythmic music intelligence is intelligence related to the ability to tone, considering i rama, pitch patterns, and colors nad a manner emosionnal with musi influence. Chatib (2013: 136) states that the core components of musical intelligence include creating and living a rhythm, with competencies including creating songs, forming rhythms, listening to tones, sound sources or musical instruments. This intelligence is in the form of a level of sensitivity to sound patterns and the ability to respond to music emotionally. Characteristics of children who have musical intelligence is like hearing music, clapping in time to the music, and capable of rhythmic voice objects, familiar songs poluper, specific, able to paint with the tool with a variety of tools, able to follow dance movements according to the song, singing songs accompanied by music, and being able to play musical instruments.

5) Kinesthetic Intelligence
This intelligence can be developed with body language and gestures. Yaumi (2012) describes kinesthetic intelligence as using all members of the body in expressing ideas, and feelings. Activities related to kinesthetic intelligence into practice dance drama include if the body, facial expression, role playing, and physical exercise, and intelligence relating to the physical motion (motion of the body and limbs). Suyadi convey kinesthetic intelligence can be characterized by children ages 1 to 6 years namely moving hands, head, prone without assistance, walking short, running, up and down stairs, climbing, walking steadily, running, kicking the ball, jumping small, happy to play with water, folding paper neatly, riding a bike, capable of cutting the paper, keep the balance of body, jump with one feet, able to wear clothes, be able to do motion acrobat, capable of cutting and pasting paper.

6) Interpersonal Intelligence

Yaumi (2012) states that interpersonal intelligence is the ability to understand the thoughts, attitudes and behavior of others. Chattib also added that component core of interpersonal intelligence is sensitivity in digesting and processing power to be exactly on mood, temperament, or others desires. Interpersonal intelligence is owned by motivators, counselors, sociologists, psychologists, and so on. High interpersonal intelligence in children aged 1 to 6 years have observed the characteristic feature of the toys hanging on it, staring at the people who are 
around, easy to mingle with the children a kid else when playing, happy to play in groups, easy to get acquainted with the girls another child, happy to be in the middle of the association of his friends, allow borrowed friends, happy lending or exchange of goods with a friend, do not cry when separated from their parents, patient waiting to play with playmates, not interfere friend intentionally, understand the rules of play well, know how to wait their turn when playing, dare to go to school without a transfer, orderly use tools or objects toy, able to lead the group in play, able to solve simple problems and dare to be responsible.

7) Intrapersonal Intelligence

Yaumi (2012) stated that the intelligence interpersonal is the ability to be able to be responsibility in understanding ourselves, and lives. Intelligence intrapersonal have a core competency, namely sensitivity in understanding the feelings themselves, understand the emotions themselves, as well as knowledge of the strengths and weaknesses. This competency includes the ability to know yourself deeply, intutively, and self-motivated, sensitive to self-worth and life goals. Children aged 1 to 6 years who have intrapersonal intelligence have characteristics including like to think, likes to convey the ideals, have a confidence high, set the time well, often show things that pride to others, and can control emotions.

8) Naturalist Intelligence

Naturalist intelligence is the ability to recognize various types of flora (plants), fauna (animals), and natural and other phenomena, such as the origin of animals. Suyadi (2010) Children aged 1 to 6 who have high naturalist intelligence are interested in playing in the wild, enjoy seeing pictures of natural landscapes, are happy to see simple interactions with the environment, like to play with natural objects, make creations from nature, distinguishing natural objects according to their characteristics, and so on. Implementation naturalist practice dance drama in learning the art of dance and drama is necessary for drama acting natural, environmental and problem respond to natural and natural, not overdone.

9) Existential Intelligence Susanto (2005: 71) convey children who have existential intelligence in general tend to be critical about the existence of the world, searching for the meaning of life's, related to the death, and the reality of life. Existentialist intelligence is possessed by religious figures, spiritual figures, Sufis, and so on.

\section{RESEARCH METHODS}

This study used a qualitative descriptive research method based on Lesson study with an empirical approach using a deductive line of thought. This research is sourced from existing data in the field as a source of primary data by observing student activities in the drama learning process for 16 face-to-face meetings including midterm and final semester exams. The purpose of 
empirical research is for researchers to see during the learning process in dance and drama education courses and pay attention to the existence of multiple intelligence in each prospective primary school teacher for one semester (7th semester) of 38 students in the 2019/2020 school year in the drama project creation process. group. The deductive line of thought is a system of thought with general and abstract problems leading to specific and concrete characteristics. The research design for 1 semester is as follows

\section{1). Plan}

Planning Phase Activities carried out at this stage are as follows;

(a) Arranging basic competencies and learning objectives at each meeting,

(b) Preparing initial performance tests to determine the extent to which students' abilities and skills are related to drama and dance

(c) Prepare research instruments.

(d) Prepare observation sheets for group learning activities.

\section{Do Implementation}

(a). Divide the class into 2 drama groups

(b). Deliver basic competencies and learning objectives

(d). Implementing motivational learning strategies, reinforcement

(e). Presentation, Evaluate and record findings

(f). Carry out a final performance test.

3) Observation and Action Evaluation Phase (a). Observe the Learning process for 16 meetings and record research findings

(b). Evaluating the performance of drama and dance projects

(c). See

Provide assessment of dance drama projects as a result of individual and group performance

(d) Summing up the multiple intelligences in each student After the research data were obtained, editing, classification, verification, analysis and drawing conclusions were carried out.

\section{RESULT AND DISCUSSION}

A. Results

Howard Garner said that basically humans have various forms of intelligence. Multiple Intelligences which can be reflected or seen in a behavioral activity or action can be observed in the practice of composing drama music groups in dance and drama lessons.

1) Linguistic Verbal Intelligence

In finding the intelligence of Multiple I ntelligence in learning Dance and Drama Students PGSD can be classified into preparing drama steps 1) Determine the theme of the drama. The theme that has been obtained can be innovated implicitly, students can develop linguistic intelligence by practicing imitating the sounds of the animals referred to in this role, for example, such as chickens, birds, wolves, tigers, mouse deer, buffalo, and so on. 2) Develop a good language in a musical drama script. Prospective elementary school teacher students who become actors and 
actresses must have linguistic verbal intelligence by reading the script repeatedly so that the dialogue in the script can be memorized, even linguistic intelligence allows for mastery of language in the script, as well as developing language, word structures in the dialogue contained in the script so that it can animate its role properly.

2). Intelligence Logic of Mathematics

The intelligence of mathematical logic in learning musical drama practice is seen in the attention to the duration of time in acting out the drama. Dramas are compiled with a predetermined duration based on the scenario or script, but after being presented the can changes to a longer or shorter time because dramas that prioritize creativity, can rely on sudden spontaneity to cover up the mistakes or weaknesses that occur during the musical drama stage. This is related to controlling his acting so that it is not excessive, wordy over a predetermined time limit or duration.

3) Visual Spatial Intelligence

Visual intelligence in learning the dance drama looks at blocking. Blocking is a drama character's self-positioning in knowing the stage layout where he or she must stand, move places, move appropriately and intelligently by considering the visual spatial. In addition, to intellegence visual spatial required when actors or artists in applying makeup in accordance with the visualization of the character or role. Because prospective teachers must apply makeup to themselves according to their imagination and visualization, character and character in the role. Make up skills, requires considerable practice and experience. Full body makeup is no exception clothes, hands, feet, neck, hair, social condition, and so on. Apart from stage and make-up, multiple intelligence is needed in decorating and lighting in the creativity of SD musical drama's. Apart from being actors and artists, prospective primary school teacher collaborate in groups to make their own decorations.

Selecting and express and innovate the decoration of second-hand goods, changed in a way become a unique decoration and useful in supporting dramatari stage. By conducting a series circuit keg iat late to cultivate intelligence visual spatial, prospective teachers can be $r$ of imagination in depicting the visual, creative imagination with all the appropriate consideration in an effort to try find a way of solving, so it can show the best for them for everything something related to working on drama.

4) Musical Intelligence

Intelligence music rhythmic in drama practical learning that intelligence in response to music with various rhythmic motion response in harmony with accompanying music. Shape music or accompaniment role is to give effect to psychiatric so that it can turn on agenda and build atmosphere. Various types of sounds or music are displayed in dance drama scenes, because the function of accompaniment or music according to Waluyo (2001) is to provide illustrations that can provide a beautiful setting, 
provide psychological color, help in accentuating plays, and depicting scenes.

In fact, capital k e skills, the art of the student teachers are lacking, then usually prospective teachers of students who have shyness, lack of confidence that will require practice and adjustments to be able to express its movement through music, but it is also a role protagonis, Antagonists and tritagonists are required to express their musical intelligence to sing and dance according to the accompanying music. On the side of the prospective teachers are given to freedom of expression, is not bound by the rules and wrong but the whole is still in a brick s norms in force.

5) Kinesthetic Intelligence

Application of kinesthetic intelligence in learning the art of dance and drama that use the body to express themselves artistic and aesthetics by dancing and playing the drama. Kinesthetic intelligence in playing the drama musical, by practicing body exercises, continuous expression or mimic exercises and realizing the body's response to sad, happy, tense confusion, pleasant atmosphere, uncertainty, will harmonize thoughts that are expressed or expressed in the form of body movements beautiful, creative and meaningful. PGSD students who have aesthetic intelligence can be recognized by their appearance when dancing or moving by showing their graceful and supple or flexible movements.

6) Interpersonal Intelligence

Implementation intelligence exersice interpersonal in drama, as described by
Wright (1971) that candidate actors must have a sense of the expression of his expression, sensitive to the atmosphere of the stage, sensitive to the spectators, and atmosphere as well as the accuracy of proportional contained in the role.

7) Intrapersonal Intelligence

In fact, the application of this dramatic learning practice sharpens interpersonal intelligence. Interpersonal intelligence in learning dramatic practice requires creativity and a flexible attitude. The idea of creativity and flexible attitude leads players to understand acting as a creative artistic expression. Natural acting will create an illusion that creates attractiveness by building a person's character in the drama. Personal quality will be awakened by increasing the frequency of training related to physical character, emotional response (controlled emotions will always be ready to respond to situations in the play or scene), and mental.

Edward (1972) shows the conditions for conveying mastery of actors namely: sensitivitas, sensible, good personality, power imanjinasi strong and good mental and physical stamina. By engaging in dialogue, acting, communicating, singing, dancing trains students' self-confidence, learning to dare to express their ideas, feelings that are thought to be actualized in the seriousness of individual performance. Even though they have individual responsibility, students can control their emotions of anger, sadness, tension, and happiness to present group dance dramas with the commitment and 
sincerity of a solid team to produce good drama works.

8) Naturalist Intelligence

In drama learning that raises the social environment about waste, for example, a response to the logging scene is needed, maintaining the cleanliness of the sea and marine ecosystems, and all of that requires naturalist intelligence to respond appropriately so that it can be shown in a naturalist drama staging and there is a logical storyline in the drama musical.

9) Existential Intelligence

One of the applications of existentialism intelligence among teacher-to-be students is in determining the moral message of dance drama. This dance drama is intended for elementary school students, so there is a need for a moral message of life as a reflection of the drama being performed, because drama is an imitation of life. The moral message in the drama must be conveyed to the audience, so that the audience (elementary school students) can have a positive psychological influence so that there is a phase of reflection on what happens (cause and effect) after the audience witnesses the dance drama performance. As Aristotle (Brahim, 1968: 52) argues that drama is a representation of action. Through drama, can be a teacher for life. Drama is a reflection or reflection of life, allowing us to see, reflect on, observe and recognize solutions to problems in life.

B. Discussion

1.Technical Dance Drama Learning
Practical learning of musical drama is divided into several groups, not randomly, but given the freedom to choose members in the group. This is based on closeness and good relations between students with one another so that the assumption of a good relationship in friendship will support the process of musical drama work with few obstacles. This strategy is successful, as a whole all students can apply good cooperation and discipline in learning. The research findings obtained from this research are that the understanding of the various kinds of intelligence of students is not only limited to one type of intelligence, but it does not rule out that students have many types of intelligence even though they are inversely proportional to their academic intelligence. This is in line with the conclusions of Rofiah's (2016) research by understanding that each individuals from birth have various types intelligence, it is hoped that educators will not just assume that students are smart and achievers are only students who have academic intelligence.

\section{The Process of Learning Dance and Drama}

After the workout is with programmed and scheduled, they will report its performance to the lecturer, to give each other advice and input that criticism is constructive. In this activity it becomes interesting, because each student is given the freedom to give assessments, provide reinforcement, support or give rebuttal to the work of 
other groups with the power and subjectivity point of view expressed by each student. The process before the stage, and the next is reflection. Students will reflect on their own drama and provide others and begin to learn about the diversity of forms and styles of presentation of drama that originate from various sources of work, one of which comes from the experiences of each student who contributes thoughts in working on the drama. Reflection on learning in the findings of this study is the courage and self-confidence of students that still need to be improved by giving assignments in the form of individual and group exercises outside of learning hours, structured motivation and feedback.

3. Dance and Drama Learning Strategies

Apart from the efforts and hard work to achieve the above performance, the importance of motivation is the basis for driving performance to achieve quality musical drama learning. This statement is in line with Mohamad (2013) which states that it takes effort and motivation to improve the quality of learning, so as to optimize student intelligence.

In drama learning, drama learning strategies are needed that are designed appropriately to condition students with the achievement of drama learning outcomes according to the targeted competencies. The strategy implemented in previous research (2016) was by implementing the Cegera strategy in learning the motion of the Early Childhood Education student songs with the stages of learning strategies.
4. Multiple Intelligences in Learning Dance and Drama

Drama learning relies on process, not outcome. The experience of working in drama, dancing, singing, music, composing stories, setting decorations, characterizing, dialogues, telling stories, expression, and all the values of good characters become a unit of activity as a standard of competence. The competency standard in drama learning is that students follow the learning process with the final result, namely the ability and skills in demonstrating drama in accordance with the competency standards of musical drama learning. Agree with Selaras (2013), while Sholeh (2014) adds that the process of transferring knowledge from teachers to students in learning will be successful if the available time is focused on the condition of students in activities, not on conditions of teaching teachers. This can be found in drama learning. The Parmi model is applied in drama learning. For educators, the use of the Parmi (Parsipatory Multiple Intelligence) model in learning to write scientific papers with only $30 \%$ teaching time, while $70 \%$ is used for student activities.

So the teacher's strategy in setting up learning so that the practice of musical drama learning is enforced is not much different in percentage, namely $40 \%$ theory and $60 \%$ practice. Although in practice, theory is given at the same time as students practicing drama. Because there are several drama theories that must be put into practice in order to facilitate understanding so that students 
get an overview of drama theory with direct practice. Based on the musical drama practice activities, the teacher provides a positive and objective response in an effort to generate student performance and participation in various forms both contributive and initiative.

In accordance with Aryani ( 2014). Aryani's statement in his research regarding the learning model based on the theory of Multiple Intelligence which is dominant in the subject, the pressure is that an appropriate learning strategy is needed by looking at the tendency of the student's intelligence so that learning can be carried out properly. The key to success in learning musical drama from the training process to the performance is emotional management between teachers and students. Emotional management by providing instruction, encouragement and moral messages to encourage performance and success in students of primary school teacher education in learning progress. The statements of Ardimen (2016); Masdudi (2017); Utami (2019) reinforce important notes in the discussion of this research that focuses on learning musical drama practice by applying multiple intelligences, found several findings on the application of Multiple Intelligences, namely:

1) Tools to achieve success are more concerned with the process to achieve results,

2) Integrative learning that combines various intelligences,

3) Learning is full of challenges, and learning becomes more fun,
4) Concern for the individual differences of students so that emotional management is needed, and,

5) Instructions and instructions based learning,

6) The importance of reflection for further improvement,

7) Clarity of targets, and the achievement of each student's competence.

\section{CONCLUSION}

During one semester, 16 face-to-face meetings and out-of-class lessons for prospective elementary school teachers have been equipped with creative and innovative dance drama training skills and experiences. Learning dance and drama as compulsory subjects for the Elementary School Teacher Education study program is taken in semester 7. Drama as a dialogical literary work is an imaginative portrait of life or an interpretation of life, so studying drama has the intention of finding many things to become an independent, capable human. stand alone, with a reflection of life and life, responsible for behavior in life so as to be able to overcome conflicts or problems in his life. life. PGSD Drama Learning, which is integrated with the content of character values, is important for strengthening one's identity, developing a positive imagination, fostering more humanistic moral values in the audience. So, it can be underlined that creative and innovative drama learning requires nine intelligences (multiple intelligence). Prospective teachers (PGSD students) as students 
can develop multiple intelligences in the practice of drama in dance and drama education courses. On the other hand, prospective teachers need to gain insight into the various characteristics and multiple intelligences of students, so that tolerance for diversity can be understood and by implementing role playing methods. Learning dance and drama that is meaningful, creative, innovative, and fun can be an option in developing multiple intelligences so that the Multiple Intelligences will become an effective platform for determining 21st century learning strategies.

\section{REFERENCES}

Ardimen. (2016). Development of Multiple Intelligence through Games-Based Integrative Learning (Model Integration of Guidance in the Learning Process as Efforts to Develop Students' Intelligence Potentials. Journal of Education Vol 2, Number 2, July 2016.

Aryani, DA, Sudjito, DN, et al. (2014). Learning Model Based on the Dominant Multiple Inttelegence Theory in the Classroom on Educating Pressure Material. Volume VI Number 02 Year 2014, $130-136$.

Brahim. (1968). Drama in Education. Jakarta; PT Gunung Agung.

Btitton, Lesley. (1992). Montessori Play \& Learn: A Parent's Guide Purposeful Play From Two Six. New York: Crown Publisher, Inc.
Bruce, Tina. (1987). Early Chilhood Education. London: Holder \& Stoughton.

Chatib, Munif. (2013). Human Teacher: Making All Children Special and All Children Champions. Bandung: Champion, Kaifa.

Zakiah Daradjat, et al., (1996) Islamic Teaching Methodology. Jakarta: Earth Literacy.

Endraswara, Suwardi. (2014). Dramatic Learning Methods: Appreciation, Expression and Assessment. Yogyakarta: CAPS (Center of Academic Publishing Servise).

Istiningsih, and Nisa, AF. (2015). Implementation of Multiple Intelligences in Basic Education. Al Bidayah Journal -The Basic Islamic Education Journal. Vol 7 No 2, December 2015.

In tune, $\mathrm{GH}$, Anhar, $\mathrm{A}$ and Sumarmin. (2013). The Relationship between Multiple Intelligences and Biology Learning Outcomes of Class X Sman Students in Padang City. Collaborative Journal. Volume 1 No 12013.

Slamet, Retno Winarni, et al. (2016). Primary School Drama Dance Education Assessment. Surakarta: UNS Press.

Suyadi \& Dahlia. (2017). Implementation and Innovation of the 2013 Paud Curriculum: Learning Program Based on Multiple Intelligences. Bandung: PT Remaja Rosdakarya. Gardner, H. (1983). Frames of Mind: The Theory of Multiple Intelligences. New York: Basic Books. 
May Lwin, et al. (2003). How to Multiple Yout Child Intelligence: How to Develop Multiple Intelligences. Yogyakarta: trans. Index.

Masdudi. (2017). Multiple Intelligence Learning Concept for Early Childhood. Alwady's Journal: Children's Education Journal. Vol. 3 No. 2, September 2017.

Mohamad, S.N., (2013). A Self-Perceived Analysis of Students Intelligence and Academic Achievement. Australian Journal of Basic and Applied Sciences. 7 (3): 51-55.

Montessori, Maria. (2016). Scientific Pedagogy as Applied to Child Education in The Children House. English: Anboco

Muhmidayeli. (2011). Educational Philosophy. Bandung; PT Refika Aditama.

Purwatiningsih and Ninik Harini. 2002. Elementary School Dance-Drama Education. Malang: State University of Malang.

Rofiah. (2016). Applying Multiple Intelligence in learning in Elementary Schools. Journal of Basic Education Dynamics. Volume 8, No. 1 March 2016.

Savitri, Maya Ivy. (2019). Montessori for Multiple Intelligences. Yogyakarta; PT Bentang Pustaka.

Sholeh, Khabib. (2014). Participatory Multiple Intelligences (PARMI) Model for Learning Writing Scientific Papers. Journal of Dialectics Vol. 1 No. 2
Siswantari, H., \& Maretha, A. (2020). Evaluation Instruments of Dance Learning Outcomes Based on Theory of Multiple Intelligences in Elementary School. Journal of Teaching and Learning in Elementary Education. 3(2), 168181.

Susanto, Handy. (2005). Application of Multiple Intelligence with Learning Systems. Journal of Sower Education. No 04 Vol IV, July 2005. Suyadi. (2010). Psycholoy of Learning. PAUD, Yogyakarta: Pedagogy.

Suyadi. (2017). Implementation and Innovation of the 2013 PAUD Curriculum. Learning Program Based on Multiple Intelligences. Bandung; PT Remaja Rosdakarya.

Utami, Sri Weni. (2019). 21st Century Education In Education And Learning: Multiple Intelligences. Proceedings of the National Seminar \& Educational Psychology Call Paper, 21 April 2019.

Wijayanti, Okto. (2016). Implementation of Product-Based Immediate Learning Strategies for PGPAUD FKIP Muhammadiyah University Purwokerto Students. The Treasure of Education. Educational Scientific Journal, Vol. X, No. 1

Wright, Edward. (1972). Understanding Todays Theater. London: Practice Hall, Inc.

Yaumi, Muhammad. (2012). Multiple Intelligences Based Learning. Jakarta: Dian Rakyat. 